\title{
Information Exchange and Use among Actors Involved in Tanzania's Local Primary Education Governance: Insights from Social Network Analysis in Two Mvomero District Villages
}

\author{
Nathalie Holvoet (Corresponding author) \\ Institute of Development Policy, University of Antwerp, Lange St. Annastraat 7, 2000 \\ Antwerpen, Belgium \\ E-mail: nathalie.holvoet@uantwerpen.be
}

Liesbeth Inberg

Institute of Development Policy, University of Antwerp, Belgium

Elizabeth Genda Lulu

Institute of Development Studies, Mzumbe University, Tanzania

Yona Matekere

Institute of Development Studies, Mzumbe University, Tanzania

Received: July 29, 2018

doi:10.5296/jet.v6i1.13592
Accepted: August 14, 2018

Published: December 31, 2018

URL:http://dx.doi.org/10.5296/jet.v6i1.13592

\begin{abstract}
It is nowadays widely acknowledged that the exchange of information, both horizontally and vertically, between different actors involved in governance processes is critical for reaching outcomes. One way to grasp local governance realities is through social network analysis which is particularly apt to map and understand patterns of relations among a delineated set of actors. This article draws upon data from a network survey among actors involved in primary education governance in two Mvomero district villages to study information exchange and use. As informal relations and institutions tend to be equally important, we also map and analyse informal relations between the different actors. Findings amongst others reveal that there is hardly any (horizontal) exchange of education- related information between the two villages. This lack of exchange among village actors that are similarly positioned foregoes opportunities to combine resources and creates a learning deficit in solving similar education-related problems.
\end{abstract}

Keywords: Local Governance, Information Exchange, Social Network Analysis, Primary Education, Mvomero District 


\section{Introduction}

The importance of governance to reach education-related goals has repeatedly been underscored by policy makers and academics alike (see e.g. 2009 UNESCO Education for All (EFA) Global Monitoring Report). Governance in the education sector relates to the formal and informal processes of formulating educational policies and allocating resources, the processes of decision-making as well as the mechanisms to hold government accountable. It generally involves a myriad of government and non-governmental actors positioned at different levels (from ministry level to community and schools) and holding different degrees of authority and influence (see http://unesco.org).

In particular the exchange of information among the actors involved proves to be critical for governance processes and outcomes. In their research Bodin and Crona (2009) demonstrate how networks among actors contribute to information sharing and knowledge transfer. The inclusion of different kinds of actors in governance processes provides access to different types of information and knowledge, which increases collective learning as well as the probability to find solutions for governance problems (Daly \& Finnigan, 2011; Pahl-Wostl et al., 2012).

As different settings have their own governance systems and networks, government reforms might work in one area or sector, while they might fail elsewhere. A 2008 UNESCO study demonstrated that one of the reasons why governance reforms in the education sector have not always been successful is exactly the inclination to apply blueprints which tend to disregard local circumstances (UNESCO, 2008). From this vantage point, one may understand the critical importance of grounded knowledge of what locally exists. One way of grasping local governance realities is through the use of Social Network Analysis (SNA) that focuses on mapping and understanding patterns of relations among a delineated set of actors. While the use of concepts and methods of SNA has nowadays become common practice in sectors such as water and environment (see e.g. Bodin \& Croda, 2008, 2009; Rathwell \& Peterson, 2012; Stein et al., 2011), it has thus far not been not often been applied in the education sector (Herz, 2014).

This article contributes to filling the gap and uses SNA to study local (primary) education governance processes in two neighbouring villages of Mvomero district situated in Tanzania's south-eastern Morogoro region. Our research specifically focuses on the exchange of education-related information among different actors who are directly and indirectly involved in education governance and situated at village, ward or district level. In addition we include civil society actors such as Non-Governmental Organisations (NGOs), media as well as churches and mosques which potentially play a role in local information exchange.

As we are not merely interested in the exchange of information but also in its usage, we also study the use of information to bring about changes, which most often relate to increasing quantity and quality of the educational offer. We differentiate between horizontal exchange of information among actors positioned at the same level and vertical exchange of information between different levels as previous research (see e.g. Andersson, 2004; Fox, 2001) has highlighted that both types of exchange are important for learning, although in slightly different ways. We also adopt a comparative perspective and analyse differences among the two 
neighbouring villages, specifically comparing the exchange and use of information by and between actors who hold the same position in each of the villages. In addition we analyse the characteristics of the most central actors in the network. Finally, as earlier research (see e.g. Bodin \& Crona, 2009; Stein et al., 2011) has demonstrated that informal relations and institutions tend be equally important in governance as formal relations and institutions, we also map and analyse informal relations between different actors.

The structure of this article is as follows: the next sessions provide a brief overview of social network analysis and actors involved in the local governance in Tanzania's primary education sector, after which a brief account is given of the methods used. Subsequently the findings of the social network analysis are presented and discussed. The last section concludes.

\section{Social Network Analysis}

Starting from the premise that information exchange is important for governance processes (see Bodin \& Crona, 2009), this article studies information exchange among actors involved in the governance of primary education in two villages in Mvomero district. As exchange of information can be represented as social networks, with the actors that send and receive information as nodes in the network and the exchange of information between them as relations (ties) between nodes, a useful approach to study information exchange is Social Network Analysis (SNA) (Haythornthwaite, 1996). SNA specifically differs from more conventional analyses through the focus on actors and relations, instead of on actors and their attributes (Hanneman \& Riddle, 2005). In what follows we give a brief account of SNA concepts which are particularly applicable to our study context.

A first important distinction with SNA is between the study of complete networks on the one hand and ego-centric networks on the other hand. While the former map and analyse relations between a delineated set of actors, the latter focus on relations from one individual actor (Herz, 2014). A key concept within SNA is 'density' referring to the degree of connection in a group of actors which is measured by dividing the number of relations (ties) actually present by the number of possible relations (ties) (Wasserman \& Faust, 1994). In our study we calculated density of the complete network to get insight into the intensity of information exchange and use and the overall connectivity of the network. Additionally, we analysed density within and between groups situated at different levels which allows identifying the connectivity within groups and between groups (Durland, 2005). Whether information between two actors is exchanged in both directions is captured through the SNA notion of 'reciprocity' (Hanneman \& Riddle, 2005).

When studying the exchange of information between different actors, we differentiate between horizontal exchange of information among actors situated at the same level of governance and vertical exchange across levels. Both types of exchange are considered important for learning, although in slightly different ways. Actors who are situated at the same level tend to have access to similar types of information which often results in exchanging experiences in solving similar problems (Andersson, 2004) while actors that are situated at different levels often have access to different kinds of information which increases the available evidence base (Fox, 2011). In his research on the effects of the intensity of horizontal and vertical linkages on governance 
outcomes, Andersson (2004) demonstrates that particularly intense horizontal connections, which were specifically facilitated through NGOs, have positive effects on governance outcomes. Others (see e.g. Fox, 2001) rather emphasize the importance of two-way vertical exchange among district level education actors who are more involved in policy-making and village level actors who have better insight into local level implementation. According to Fox (2001), it is particularly this bridging of the policy/implementation gap that is critical to improve service delivery.

In addition to horizontal and vertical exchange of information, we analysed if homophily has an influence on the exchange of information. Homophily is the phenomenon of "actors sharing similar attributes forming ties over time at higher rates than dissimilar individuals" (Daly \& Finnegan, 2011, p. 48). Actors with similar attributes are for example actors who hold similar positions or who have a working relation (Daly \& Finnegan, 2011).

Central actors in the network, actors who send and receive most information, can be identified by calculating the in-degree and out-degree centrality, which discloses information on the number of links to and from an actor respectively (Durland, 2005). Central actors are often at close distance from other actors in the network. Within SNA the shortest possible distance between two actors is referred to as geodesic distance (Durland, 2005).

For the most central actors in the network we also calculated brokerage roles in order to get insight into the links between different groups of actors. The specific brokerage roles that central actors can play are dependent on the groups to which the sender and the recipient of information and the broker belong (see Table 1).

Table 1. Overview of five different brokerage roles

\begin{tabular}{ll}
\hline Coordinator & $\begin{array}{l}\text { Sender, recipient of information and broker belong to the same } \\
\text { group }\end{array}$ \\
\hline Liaison & $\begin{array}{l}\text { Sender, recipient of information and broker all belong to } \\
\text { different groups }\end{array}$ \\
\hline Gatekeeper & $\begin{array}{l}\text { Recipient of information and broker belong to the same group, } \\
\text { sender belongs to another group }\end{array}$ \\
\hline Representative & $\begin{array}{l}\text { Sender and broker belong the same group, recipient belongs to } \\
\text { another group }\end{array}$ \\
\hline Consultant & $\begin{array}{l}\text { Sender and recipient belong to the same group, broker belongs } \\
\text { to a different group }\end{array}$ \\
\hline
\end{tabular}

Source: Hanneman and Riddle (2005)

In order to get insight into the extent to which the exchanged information is used for learning, we divided the number of relations present in the use-of-information network by the number of relations present in the exchange-of-information network. As actors are usually not only connected in one way, but in multiple ways (Hanneman \& Riddle, 2005), we have also mapped 


\section{Macrothink

and analysed informal relations between the different actors in the network as well as the overlap with the exchange and use-of-information networks.

\section{Local education governance in Tanzania}

The 1999 Local Government Reform Programme sets out the policy for devolution of functional responsibilities, which for instance includes strengthening of local accountability and the involvement of local communities in the planning and execution of service delivery projects (Venugopal \& Yilmaz, 2010). As regards the education sector, several actors at district, ward and village levels are directly or indirectly involved. Table 2 provides an overview of the main actors, divided by level of involvement.

Table 2. Overview of different actors involved in local education governance

\begin{tabular}{|c|c|}
\hline Level & Actors \\
\hline District & $\begin{array}{l}\text { - District Executive Director (DED) } \\
\text { - District Commissioner (DC) } \\
\text { - District Council } \\
\text { - District Education, Health and Water Committee (DEHWC) } \\
\text { - District Internal Auditor (DIA) } \\
\text { - District Planning Officer (DPO) } \\
\text { - District Primary School Inspectorate (DPSI) } \\
\text { - District Primary Education Officer (DPEO) }\end{array}$ \\
\hline Ward & $\begin{array}{l}\text { - Ward Councillor (WC) } \\
\text { - Ward Development Committee (WDC) } \\
\text { - Ward Executive Officer (WEO) } \\
\text { - Ward Education Coordinator (WEC) }\end{array}$ \\
\hline Village & $\begin{array}{l}\text { - Primary schools } \\
\text { - Village Executive Officer (VEO) } \\
\text { - School boards } \\
\text { - Village General Assembly (VGA) } \\
\text { - Village Council (VC) } \\
\text { - Village Education Committee (VEC) }\end{array}$ \\
\hline $\begin{array}{l}\text { Civil } \\
\text { Society }\end{array}$ & $\begin{array}{l}\text { - Media } \\
\text { - NGOs } \\
\text { - Churches } \\
\text { - Mosques }\end{array}$ \\
\hline
\end{tabular}

Important decisions on planning and budgeting take place at district level with lower levels disposing of limited legislative or decision-making power in practice (Venugopal \& Yilmaz, 2010). At district level, the District Commissioner (DC) represents the central government and the party (Chama Cha Mapinduzi, CCM) and officially reports to the Prime Minister's Office (interviewee). While the DC has in reality substantial, but rather informal power (Harris et al., 


\section{Macrothink

2011; Hoffman, 2013), the District Executive Director (DED), i.e. the head of the local government administration, is formally the most powerful civil servant in the district. The DED is e.g. responsible for approving budgets and projects (Harris et al., 2011) and reports to the Prime Minister's Office and the DC. The elected officials, councillors and members of parliament have little formal power, but as they are elected, they tend to be the most accountable set of actors (interviewees; see also Kaduma et al., 2011).

At district level other actors that are not exclusively involved in education include the District Planning Officer (DPO), who is in charge of planning, budgeting, monitoring and evaluation of development projects, and the District Internal Auditor (DIA) who is responsible for auditing the spending of the Capitation Grant and other district funds. Specific primary education actors at district level include the District Primary Education Officer (DPEO) and the District Primary Education Inspectorate (DPEI) who are responsible for ensuring and monitoring primary education and for the inspection of primary schools respectively.

At ward level, the Ward Councillor (WC) is the chairperson of the Ward Development Committee (WDC), which is in charge of the general supervision of education, health and water issues. WCs are members of the district council but they are elected at ward level during general elections. The Ward Executive Officer (WEO) is appointed by the DED (Harris et al., 2011) and responsible for revenue collection, developmental issues and law-and-order functions at ward level (Braathen et al., 2005). The Ward Education Coordinator (WEC) supervises all education activities at ward level, including e.g. the monitoring of service delivery and attendance of teachers and students as well as the involvement of the community (United Republic of Tanzania, 2013). Information from the primary schools is compiled by the WEC and reported to the DPEO and the WEO.

At village level, primary schools are the main actors of service delivery and the key source of educational information. Resources and responsibilities are delegated to school management committees/school boards, with the aim to improve the accountability of civil servants and service delivery units by providing the demand side a voice (Prinsen, 2007). The effective involvement of parents in school boards is however not always straightforward. In their study covering six districts (including Mvomero), Manara and Mwombela (2012), highlight that parents' participation in school planning is largely cosmetic, amongst others due to the fact that school plans are often not distributed prior to the meetings. School boards are formally accountable to the district, through the obligation to send minutes to the DPEO, but in practice minutes are hardly ever sent (Prinsen, 2007).

Village level actors are not directly involved in education, as schools are directly (formally) linked to the ward level. Village Executive Officers (VEOs) are appointed by the DED (Harris et al., 2011) and report to the WEO (interviewees). VEOs are responsible for revenue collection, developmental issues and law-and-order functions at village level and are also the secretary of the Village Council (VC) (Braathen et al., 2005). The VC consists of a chairman, the chairmen of all the hamlets of the village and at least 15 and not more than 25 village councillors (Uwazi, n. d.). All villagers aged above 18 years are member of the Village General Assembly (VGA) (Uwazi, n. d.) which is the sovereign oversight body at village/hamlet level and whose role is in practice rather consultative (Cooksey \& Kikula, 2005; Venugopal \& Yilmaz, 2010). 


\section{Macrothink

Another set of actors that could potentially play a role in local governance processes include civil society actors and informal institutions such as NGOs, local media, religious institutions, etc. According to Venugopal and Yilmaz (2010), thus far, civil society actors did not really take up a role in bottom-up accountability which may partially be explained by the absence of laws which impose the participation of civil society in decision-making and the more deep-rooted culture of open conflict avoidance. Recently, media actors have become more vocal in Tanzania, despite the fact that a Freedom of Information Act has continuously been postponed. Generally, media has particularly been active in reporting on instances of CCM and government corruption scandals (see Hoffman, 2013). There are also interesting alliances emerging among CSOs and media. For instance, the NGO Haki Elimu used TV and radio in its attempts to hold government accountable for its promises on primary education (see Hoffman, 2013).

Citizens in Tanzania often rely upon institutions with religious foundation. In their study on bottom-up accountability mechanisms, Kelsall et al. (2005) highlight that at times of increased citizens' feelings of institutional malfunctioning religious institutions tend to remain unblemished, even if in reality these institutions can be divisive and a source of conflict.

\section{Methods}

\subsection{Data Collection}

Our research draws upon primary and secondary data. Secondary data includes official documents of the government of Tanzania (e.g. policies on decentralisation and education) and academic and grey literature on local governance and Tanzania's education sector. Primary data has been collected among actors at village, ward and district level who have a direct or indirect role in primary education governance in Changarawe and Vikenge, two neighbouring villages located in Mzumbe ward of the Mvomero District. Changarawe has two public primary schools (Changarawe Primary School and Mzumbe Primary School) while one public primary school is located in Vikenge (Vikenge Primary School).

On the basis of secondary data regarding education governance in Tanzania and preliminary village studies (Matekere \& Van Aelst, 2014), we drafted a list of all relevant actors (37), with the aim to apply a complete network analysis approach. In line with Table 1, the 37 actors are subdivided into a group of 8 district level actors, 4 ward level actors, 8 and 6 village level actors in Changarawe and Vikenge respectively and 11 actors from civil society and informal institutions who are active at the 3 levels. The latter group consists of 2 NGOs (CDTFN and World Vision), Abood radio, 2 mosques and 6 churches (Roman Catholic, $7^{\text {th }}$ Adventist Church, Tanzania Assembly of God, Lutheran Church, Christian Council of Tanzania and Jehovah Witnesses).

Structured interviews with each of those 37 actors (the heads or the representatives) were conducted in July 2014. More specifically, information was gathered on personal characteristics of the interviewees (amongst others level of education, ethnic affiliation, religion, residence), organisation attributes, exchange and use of information. As the use of SNA depends on the availability of relational data (Scott, 2011), we asked all 37 actors to whom of the 36 other actors they sent education-related information during the previous year, from whom they received information and which of the received information they used for learning 


\section{Macrothink

(to bring about change). We also asked each of the 37 actors to indicate if they know the other actors informally, i.e. outside a professional context and rather as a friend, relative, etc. Finally, the actors were asked to rate the influence from other actors on their thinking and acting using a score between 0 (not at all) and 4 (very much).

In addition to the structured interviews, household surveys were undertaken in July and August 2014 with a random sample of 129 and 116 households living in Changarawe and Vikenge respectively. The response rate was approximately $98 \%$ while sample rates are estimated to be around $10 \%$ and $25 \%$ respectively (on the basis of the most recent 2012 Population and Housing Census of Mvomero District). Household surveys collected information on personal and household characteristics, access and quality of education services, availability and quality of education-related information.

\subsection{Data Analysis}

Information from the network survey was stored in a square binary matrix with all actors in the first column and first row, in which a ' 1 ' represents the presence of a relation and a ' 0 ' the absence of a relation. For the exchange and use of information networks we considered a relation only to be present if the flow of information had been confirmed by both the sender and the receiver of information. For the informal network we used unconfirmed data, which means that one actor can claim she/he knows another actor informally, while this other actor does not claim she/he knows her/him.

Relations between actors can be visualised in graphs. In this article we present three graphs which represent the flow of information between the actors situated at different levels, the use of this information for learning and the informal contacts between the different actors. The actors who are situated at the same level (i.e. Changarawe, Vikenge, ward, district, civil society) are represented by the same colour (black, different scales of grey, white). The three graphs are directed, with arrows indicating the direction of the relation between two actors (Hanneman \& Riddle, 2005), as exchange and use of information and informal relationships between two actors are not necessarily reciprocal.

In the analysis of the networks we have taken into account the complete network, sub-groups and individual actors (nodes) within the network. The UCINET software programme was used for the calculation of e.g. the density of the networks, density within and between actors situated at different levels and centrality (Borgatti, Everett, \& Freeman, 2002), for the drawing of the graphs we used the associated Netdraw programme.

\section{Findings and Discussion}

\subsection{Intensity of Information Exchange}

Figure 1 presents the information exchange between the different actors who are directly or indirectly involved in the primary education sector in the villages of Changarawe and Vikenge. The different colours of the nodes in the network represent the level at which they are active: district, ward, Changarawe, Vikenge and Civil Society (including NGOs, media, churches and mosques). The size of the nodes represents the size of the k-core, which are closely connected sets of nodes (Hanneman \& Riddle, 2005). 


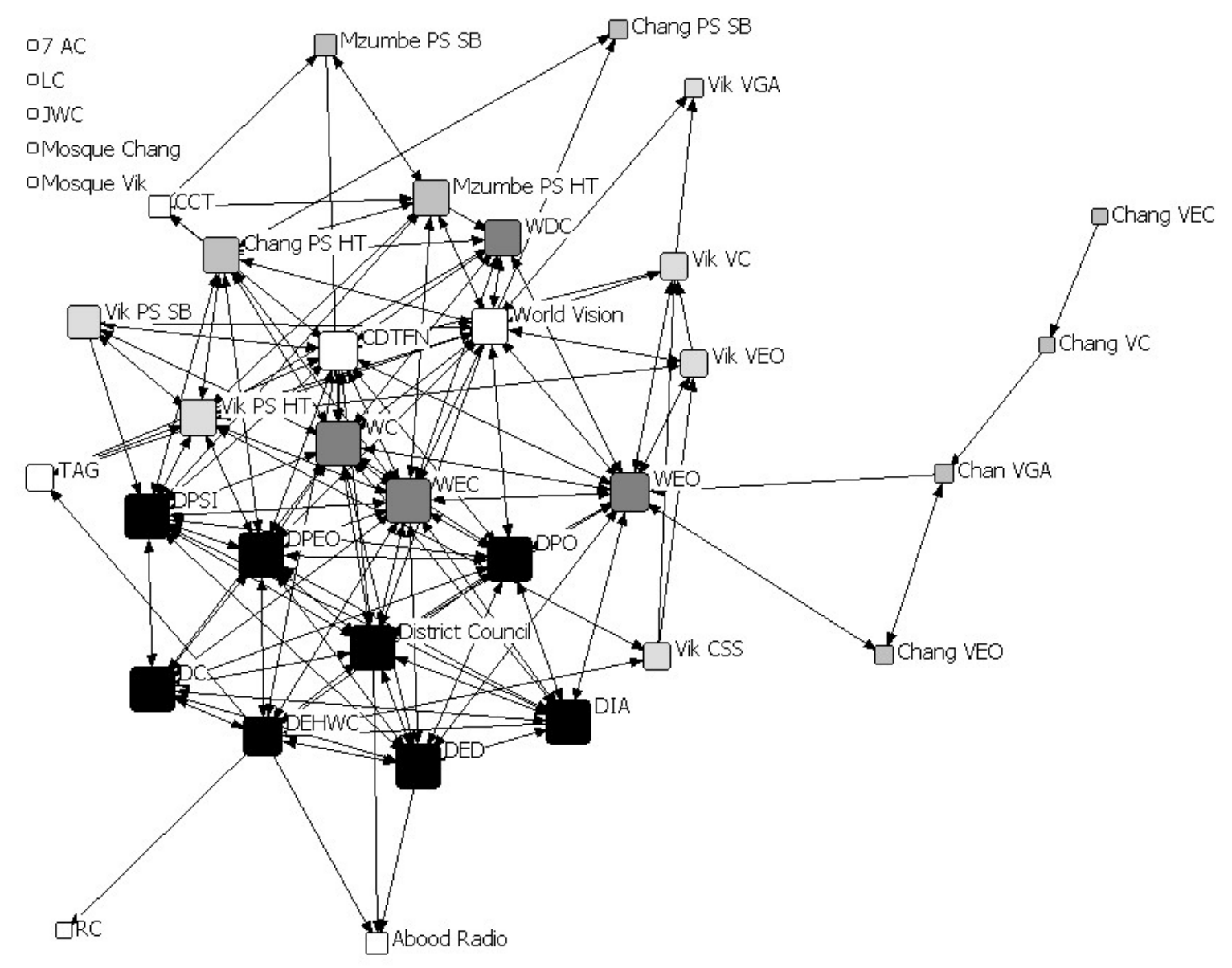

Figure 1. Information exchange network

Source: Based on authors' data collection and analysis

The network is not completely connected, as five actors (three churches and two mosques, displayed at the upper left hand side of Figure 1) who do not exchange information on education issues with the other actors are not included in the network. The density of the network is 0.168 , which means that $16.8 \%$ of the possible links (1332) (Note 1) are present. Most of these links $(88.4 \%)$ are reciprocal which implies that actors who are connected often send information to each other. The largest geodesic distance (shortest possible distance) between two actors is six. Information from the Village Education Committee in Changarawe to the similar Commission of Social Services in Vikenge, to the Roman Catholic Church and to the school board of Mzumbe Primary School has to pass at least five other actors. More than half of the actors are, however, connected either directly $(16.8 \%)$, through one other actor $(30.2 \%)$ or through two other actors (13.4\%). Except for Changarawe's Village Council and Changarawe's Village Education Committee, all village actors are within a geodesic distance of one, two or three from actors at ward and district levels.

Information exchange is highest among the ward level actors, in fact all ward level actors are reciprocally linked (density is 1), and among the district level actors (density of 0.929). Exchange of education-related information is much lower in the villages and especially among 
civil society actors (density of 0.055 ), which might be explained by the fact that most of the ward respectively district actors have a working relation which is indicative of homophily being at play (see Daly \& Finnegan, 2011). The village and civil society actors on the other hand are rather diverse and not all directly involved in education (religious institutions probably exchange information, but not specifically on education).

While information exchange within the two villages is higher than the overall information exchange, it is clearly higher within Vikenge than Changarawe (see Table 3), which is especially due to the VEO, Village Council, Committee of Social Services and school board in Vikenge who exchange more information as compared to actors with the same position in Changarawe. As Changarawe has more schools than Vikenge, including three secondary schools, the exchange of education related information was expected to be higher in Changarawe. The higher exchange of information is not necessarily related to a higher frequency of meetings. The school board of Vikenge Primary School does meet more often than the school boards of the two primary schools in Changarawe (three times a month compared to once a trimester), but Vikenge's Committee of Social Services meets less often than Changarawe's education committee (four times a year compared to monthly). The frequency of meetings of the Village Council is comparable (once a month).

\subsection{Horizontal and Vertical Information Exchange}

Table 3 provides an overview of the information exchange between the two groups of village level actors (horizontal exchange of information) and the other types of actors, in which the exchange with district and ward levels can be considered as vertical exchange of information and exchange with the CSOs and the other village as horizontal exchange of information (see also Andersson, 2004).

Table 3. Densities of horizontal and vertical exchange of information within/ from Changarawe and Vikenge and other levels

\begin{tabular}{llllllllllll}
\hline Level/ & \multicolumn{2}{c}{ District } & \multicolumn{2}{c}{ Ward } & \multicolumn{2}{c}{ CSO } & \multicolumn{2}{c}{ Changarawe } & \multicolumn{2}{c}{ Vikenge } \\
Village & send & receive & send & receive & send & receive & send & receive & send & receive \\
\hline Changarawe & 0.047 & 0.047 & 0.250 & 0.125 & 0.045 & 0.057 & 0.179 & 0.179 & 0.042 & 0.042 \\
Vikenge & 0.083 & 0.063 & 0.208 & 0.167 & 0.106 & 0.106 & 0.042 & 0.042 & 0.333 & 0.333 \\
\hline
\end{tabular}

Source: Based on authors' own data collection and analysis

While vertical exchange of information with actors at district level is limited, the highest exchange of information is from actors at village level to actors at ward level (density of 0.250 for Changarawe, density of 0.208 for Vikenge). Horizontal exchange of information is limited as well; the lowest exchange of information is between Changarawe and CSOs (density of 0.045 ) and between the two villages (density of 0.042). Studying our data in more detail highlights that similar types of actors within the two villages do not exchange education-related information with each other which is indicative of the fact that this type of homophily is not at play in the exchange of information between the two villages. This observation holds for VEOs, the chairs of the village council, the chairs of the education villages committees as well as for 


\section{Macrothink

the chairs of the school boards of the three primary schools. The only exchange of information between Changarawe and Vikenge is between the head teachers of Changarawe Primary School and Mzumbe Primary School and the head teacher of Vikenge Primary School. This does not entirely come as a surprise as the other actors at village level do not have an official role in the education sector, expect for the Village Education Committee and the Committee of Social Services. Both committees do not really intervene in specific education related substance issues such as curricula, teaching materials, teachers, etc., but rather focus on school-related social issues, including access to education, water and sanitation in schools and pregnancies of students. It could be an advantage for them to exchange information on these issues in order to solve similar problems and combine resources (see also Andersson, 2004).

\subsection{Central Actors in Information Exchange}

The Ward Education Coordinator (WEC) is the most central actor in the network with an outdegree and in-degree of 16 , which means that she sends information to 16 actors and receives information from 16 actors. Other central actors include the NGO World Vision (out-degree 16, in-degree 14) and the Ward Councillor (out-degree 14, in-degree 15). None of these central actors are Muslim, while Muslims are the largest religious group in Vikenge $(51.8 \%$ of the household survey respondents) and the second largest religious group in Changarawe (43.6\% of the household survey respondents). On the other hand, two of the central actors are Roman Catholics (WEC and Ward Councillor), which is the largest religious group in Changarawe ( $46.5 \%$ of the household survey respondents) and the second largest religious group in Vikenge (34.7\% of the household survey respondents). Among all the education governance actors Muslims are as well underrepresented (21.6\%), while Roman Catholics are slightly overrepresented (45.9\%). An explanation for the underrepresentation of Muslims might be the fact that until recently Muslims generally attached more value to religious education than universal education (interviewees).

Among the central network actors, as well as among the education governance actors, tertiary school graduates are overrepresented. While only $1 \%$ of the household survey respondents have an academic degree, two of the three central network actors hold an academic degree (Programme Coordinator of World Vision, Ward Councillor) and 32.4\% of the education governance actors. Tertiary school graduates are especially overrepresented among the district actors ( 6 out of 8 actors) and the Church leaders ( 4 out of 6 actors), which can be explained by the fact that a university degree is one of their job requirements (for the position of Imam no minimum education requirements exist, both Imams have only primary education).

The three central network actors, and especially World Vision, are positioned in such a way that they potentially act as brokers between actors at different levels. The brokerage role of World Vision confirms Andersson' research (2004) which also emphasises the importance of NGOs in facilitating connections between other actors. Particularly in less dense networks, brokers are important, as they might connect unconnected parts of the network (Daly \& Finnegan, 2011). World Vision e.g. potentially plays a brokerage role between two other actors 146 times, especially as liaison (71.2\%). Other brokerage roles the organisation could play include gatekeeper (8.9\%), representative (9.6\%) and consultant (10.3\%). (Note 2) However, as discussed in Haythornthwaite (1996), whether actors play the role of broker in practice 


\section{Macrothink}

largely depends on the individual actor who decides to forward information to other actors or not, while they might as well manipulate information (Daly \& Finnegan, 2011). As a result of this, positive outcomes of governance processes are dependent on the effective brokerage role of central actors in the network (Bodin \& Crona, 2009).

In the case of the central network actors in Changarawe and Vikenge, interviewees highlighted the brokerage role of the WEC between district and village levels (role in the vertical exchange of information). The effectiveness of her role could be negatively influenced, however, by the fact that her level of education (form four secondary) is considerably lower than most of the district level actors ( 6 out of 8 actors have tertiary level, see above), which might diminish her influence. The WEC does not clearly seem to play a brokerage role between the different actors at village level (role in the horizontal exchange of information), except between the head masters of the primary schools. Also the potential brokerage roles of World Vision and the Ward Councillor have not been confirmed through the interviews.

At district level, it is the DPSI who most often can play a brokerage role (57 times: $43.9 \%$ as gatekeeper, $31.6 \%$ as representative and $22.8 \%$ as liaison); at village level it is the head teacher of Changarawe Primary School in Changarawe (31 times: most often as liaison, 35.5\%) and the head teacher of Vikenge Primary School in Vikenge (54 times: most often as gatekeeper, $35.2 \%$ ). The head teachers are also relatively often mentioned to have an influence on the thinking and acting of other actors. This also holds for the three central actors, and in particular the WEC, who are more than averagely mentioned. This combination of being central in the network and having a lot of influence on other actors reconfirms all the more the dependence on these actors for achieving positive outcomes of governance processes. Other actors that were very often mentioned to have an influence on other actor's thinking and acting are the DED (particularly on thinking) and the DPEO (particularly on acting), who are both also relatively central in the network.

\subsection{Use of Information}

As highlighted in Haythornthwaite (1996) and Andersson (2004) exchange of information only creates opportunities if the information is also effectively used. We thus asked all actors included in the network whether they use the information received for learning. 


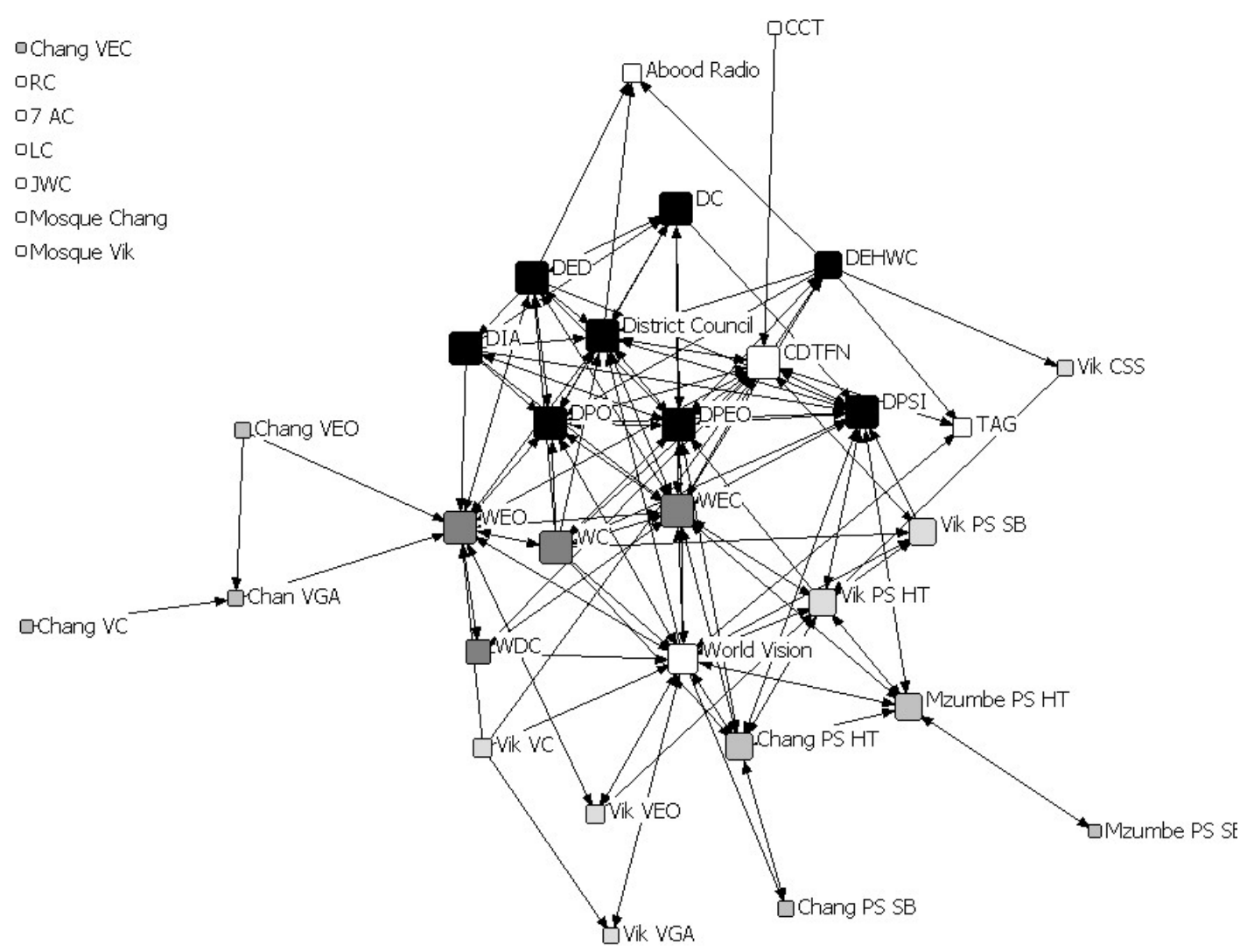

Figure 2. Use of Information Network

Comparing the networks displayed in Figure 1 and 2 clearly shows a lower density of the use for learning network (density of 0.125 ) which is indicative of the fact that not all information that is exchanged is also effectively used. However, $74.6 \%$ of the ties in the information exchange network are also present in use for learning network. Similar to the exchange of information network, this network is neither completely connected. Besides the five actors who do not exchange education related information, two other actors are not included in this network, i.e. Changarawe's Village Education Committee and the Roman Catholic Church, as the information they send and/or receive is not used.

Table 4 shows that the actors in Changarawe use all the information they receive from actors in Vikenge and from district level actors, while their information is also used by these actors. In addition all the information that is sent by actors from Vikenge is used by CSO actors.

Table 4. Percentages of information sent and received that is used for learning (in \%)

\begin{tabular}{lllllllllll}
\hline Level/ & \multicolumn{2}{c}{ District } & \multicolumn{2}{c}{ Ward } & \multicolumn{2}{c}{ CSO } & \multicolumn{2}{c}{ Changarawe } & \multicolumn{2}{c}{ Vikenge } \\
Village & send & receive & send & receive & send & receive & send & receive & send & receive \\
\hline Changarawe & 100.0 & 100.0 & 50.0 & 75.0 & 50.0 & 60.0 & 80.0 & 80.0 & 100.0 & 100.0 \\
Vikenge & 75.0 & 66.7 & 60.0 & 75.0 & 100.0 & 71.4 & 100.0 & 100.0 & 50.0 & 50.0 \\
\hline
\end{tabular}




\section{MInstitute Macrothink $_{\text {Int }}$}

Journal of Education and Training

ISSN 2330-9709

2019, Vol.6, No.1

Relatively speaking, the lowest use of information for learning is amongst actors within Vikenge. In line with the information exchange network, however, the actual density of the use of information network between actors within Vikenge is somewhat higher that the density between actors within Changarawe (0.17 compared to 0.14). In addition the density between Vikenge's actors and ward and $\mathrm{CSO} /$ informal institution actors is also higher. A relevant example of the use of information by Vikenge's actors, specifically by the head teacher of Vikenge Primary School, is the organisation of extra classes on Saturday after the poor 2012 Primary School Leaving Examination (PSLE) results were communicated. Parents are increasingly aware of the utility of these Saturday classes, as a result of which attendance increased from 50\% to almost $100 \%$ and the average mark of the PSLE increased with $81.9 \%$ in 2013 (and slightly with 5.7\% in 2014). A large majority (81.7\%) of the household survey respondents with children in Vikenge Primary School confirm the improvement in primary education quality.

Among the most central network actors, the WEC and World Vision use all of the information they receive for learning, while the Ward Councillor only uses $13.3 \%$. He only uses the information received from the DPEO, the WEO and the WEC. The information from the WEC is used by $87.5 \%$ of the actors to whom she sends information, information from World Vision by $81.3 \%$ and information from the Ward Councillor by $78.6 \%$. As table 4 shows, the head teachers of the primary schools of Changarawe use the information they receive from the head teacher of Vikenge Primary School and vice versa. The head teachers of Changarawe Primary School and Mzumbe Primary School also use each other's information.

\subsection{Informal Networks}

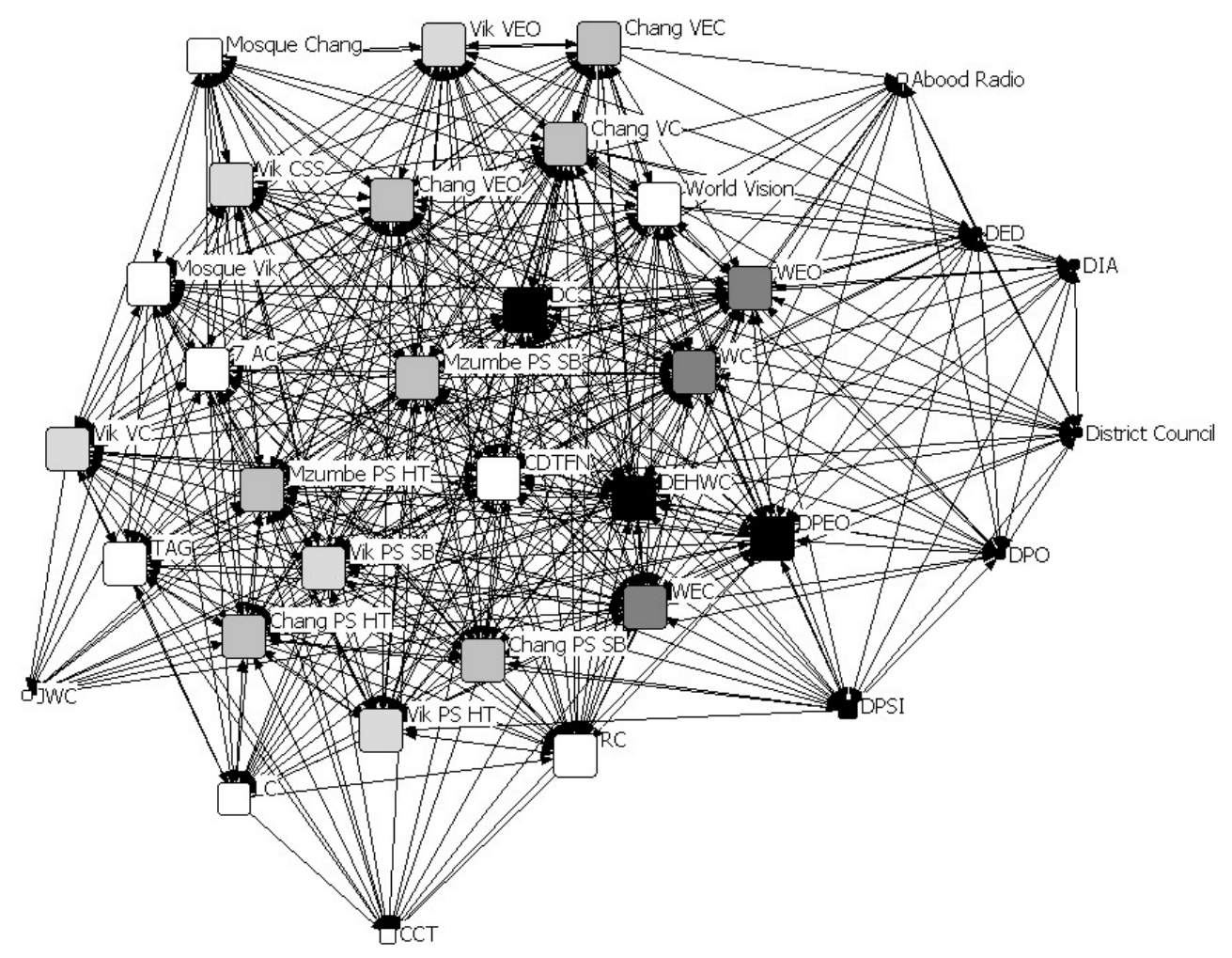

Figure 3. Informal Network 


\section{Macrothink

As informal contacts have proved to be important for governance in other sectors (see Bodin \& Crona, 2009; Stein et al., 2011), we asked all actors whether they know other actors informally. Figure 4 shows the 'informal' network, which is directed, as we used unconfirmed information; the informal relations between two actors is not necessarily confirmed by both actors (reciprocity is 0.704 ).

The density of this network (0.562) is clearly much higher than the densities of the exchangeof-information and use-for-learning networks; more than half of the actors know each other informally. In contrast to the other three networks, this network is connected, as all actors know or are known by at least another actor. Except for the CSO actors, the density within each of the other 4 groups is much higher than the overall density: 0.964 for the district level actors, 1 for the ward level actors, 0.905 for Changarawe's actors and 0.950 for Vikenge's actors.

While Vikenge's network for exchange and use of information is generally denser than Changarawe's netwerk, it is different as regards the informal relations network. The informal network within Vikenge is slightly denser than within Changarawe (0.950 compared to 0.905), but the informal network with the district, ward and CSO actors is denser for Changarawe. (Note 3) The large differences in densities between the (subgroups of the) informal network and the networks for exchange and use of information imply that, certainly at village level, informal contacts are not always used to exchange education-related information. This particularly holds for the village actors who are not directly involved in the education sector. However, this is slightly different for both Changarawe and Vikenge education committees which are dealing with education issues and who do not use their informal contacts (both chair persons know 20 other actors) to get better informed on education related social issues.

Most of the actors from Changarawe and Vikenge know more ward level actors informally than district level actors, which does not come as a surprise, as the ward level is closer to the village level. Interestingly, more district level actors claim to know actors from the village and ward level, than actors from these levels claim to know the district level actors in an informal way. (Note 4) The highest difference is for Vikenge (reciprocity is only 0.11 ); while the District Commissioner, the chair of the DEHWC and the DPEO claim to know many actors from Vikenge, various of the Vikenge-based actors did not mention the latter actors among the persons they know informally. From these three actors, especially the District Commissioner and the chair of the DEHWC, both politicians, generally mention to know more actors informally than other actors mention they know them (difference is 13 for the District Commissioner and 17 for the chair of the DEHWC). In fact the chair of the DEHWC claims to know most other actors from the network (33 out of 36), while also the District Commissioner claims to know many actors (31).

The WEC and the Ward Councillor, who are among the three most central actors in the information exchange network, are also among the actors that have a large informal network. While the third central M\&E actor, i.e. the programme coordinator of World Vision, does not know or is not known by as many actors as the actors mentioned above, he knows and is known by more actors than average (he knows 24 actors, compared to an average of 17.1 actors, he is known by 19 actors, compared to an average of 17.3 actors). 


\section{Conclusion}

As exchange of information is known to be important for governance processes, we mapped and analysed the exchange and use of education related information among actors directly and indirectly involved in the education sector in two villages in the Mvomero district in Tanzania. In addition we looked into the informal contacts between these actors, as these often tend to be equally important for governance as formal relations. We relied upon social network analysis as this approach is considered to be useful for studying relations between different actors.

The findings of the social network analysis demonstrate that horizontal exchange of information is especially present among ward and district level actors (homophily at these levels), while horizontal exchange of information between the actors at village level and specifically between CSO actors is much lower. It is particularly striking that there is hardly any exchange of education related information between the two villages. Except for the head teachers of the three primary schools, other similarly positioned actors, including actors directly involved in the education sector, do not exchange information (no homophily at village level), which limits the possibilities for learning through the exchange of experiences in solving similar problems and combining resources. Moreover, the information collected by the village actors is hardly or not used. Our interviewees point to the fact that this might be related to the perceived low quality of this information and the fact that interference in the education sector by village actors (except by the schools and school boards) is not necessary as higher levels (ward and district) are considered to work adequately. Adding to this is also the fact that local village governments have limited budgetary discretion as regards the education sector as education-related grants are directly transferred from districts to schools. Nevertheless, the village committees, village council meetings and village general assemblies are important in reaching those sections of the village population that are not yet attending school. Other channels that might become important in this regard are local media whose activities of educational follow-up are increasing while also increased internet access, particularly among the youth, might become a factor of influence in the future.

Actors of both villages mostly exchange information with actors at ward level (vertical exchange), which is not surprising as the ward level, especially the Ward Education Coordinator (WEC), is the first point of contact for the primary schools. As the ward is the intermediate level in between the district and the villages, direct vertical exchange of information between the villages and district level actors is limited. Particularly in Vikenge actors exchange and use more information among themselves and with the other actors as compared to Changarawe. The use of information regarding the poor PSLE results in 2012 contributed in Vikenge Primary School to the organisation of Saturday classes. While we do not have information which allows for scientific attribution, it is highly likely that these increased educational services contributed to better results for the 2013 PSLE.

Our findings show that the WEC is the most central actor in the network and that she is potentially also an important broker between other actors in the network, especially between actors of different levels. She uses most of the received information for learning, while also many other actors use her information. She is also an actor who knows and is known informally by other actors and she is relatively often referred to by the other actors as having an influence 
on thinking and acting as regards education issues. From this vantage point, she is a crucial actor in local education governance as she can decide which of the received information to forward to other actors, in which format as well as how to act upon all the information she receives. Strengthening the capacity of WECs could therefore be a relevant intervention to improve the quality of education governance in Mvomero district and in Changarawe and Vikenge more specifically.

\section{Acknowledgement}

The research was supported by the Flemish Interuniversity Council for Development Cooperation [Vlir-UOS Gre@t Programme] and the Research Fund of the University of Antwerp [DOCPRO4]. The authors would like to thank the interviewees and the referees. All remaining errors are solely those of the authors.

\section{Notes}

Note $1.1332=$ number of actors (37) x number of actors -1 (36) (an actor is not connected with him/herself).

Note 2. A fifth brokerage role is coordinator, in which the source of information and recipient belong to the same groups as the broker.

Note 3. District: Changarawe 0.375, Vikenge 0.075; ward: Changarawe 1, Vikenge 0.800; CSO: Changarawe 0.701 , Vikenge 0.655 .

Note 4. There is no straightforward explanation for the fact that differently positioned individuals seem to have interpreted 'knowing as a friend, beyond the job' differently. At first sight, district level interviewees have used a much broader notion of 'friendship' including as well 'acquaintances' while village level interviewees rather seem to have adopted a more narrow interpretation ('close friends'). Some further research might be useful to get more insight into linkages between the local interpretation of 'informal relations' and different individuals' attributes.

\section{References}

Bodin, O., \& Crona, B. I. (2008). Management of Natural Resources at the Community Level: Exploring the Role of Social Capital and Leadership in a Rural Fishing Community. World Development, 36(12), 2763-2779.

Bodin, O., \& Crona, B. I. (2009). The role of social networks in natural resource governance: What relational patterns make a difference. Global Environmental Change, 19, 366-374.

Borgatti, S. P., Everett, M. G., \& Freeman, L. C. (2002). Ucinet for windows: Software for social network analysis. Harvard, MA: Analytic Technologies.

Braathen, E., Chaligha, A., \& Fjeldstad, O. H. (2005). Local governance, finances and services delivery in Tanzania. A summary of findings from six councils. Joint Report NIBR, CMI and REPOA.

Cooksey, B., \& Kikula, I. (2005). When bottom-up meets top-down: The limits of local 
participation in local government planning in Tanzania. Dar es Salaam: Repoa.

Daly, A., \& Finnigan, K. S. (2011). The Ebb and Flow of Social Network Ties Between District Leaders Under High-Stakes Accountability. American Educational Research Journal, $48(1), 39-79$.

Fredericks, K. A., \& Durland, M. M. (2005). The Historical Evolution and Basic Concepts of Social Network Analysis. New Directions for Evaluation, 107, 15-23.

Hanneman, R. A., \& Riddle, M. (2005). Introduction to social network methods. Riverside, CA: University of California. Retrieved from http://faculty.ucr.edu/ hanneman/

Harris, D., Domingo, P., Sianga, C., Chengullah, E., \& Kavishe, C. B. (2011). The Political Economy of Social Accountability in Tanzania. Anti-logging Advocacy and the Mama Misitu Campaign. London: ODI, Accountability in Tanzania Programme.

Haythornthwaite, C. (1996). Social Network Analysis: An Approach and Technique for the Study of Information Exchange. Library and Information Science Research, 18, 323-342.

Herz, A. (2014). Forgotten and future connections between social network research and educational research. Zeitschrift fur Erziehungswissenschaft, 17(5 supplement), 241-256.

Hoffman, B. D. (2013). Political Economy of Tanzania. Washington, D.C.: Georgetown University, Center for Democracy and Civil Society.

Kaduma, F., Taylor, B., \& Kapongola, N. (2011). We can't change things. Dar es Salaam: REPOA.

Kelsall, T. (2003). Rituals of verification: Indigenous and imported accountability in northern Tanzania Africa, 73(2), 174-201.

Manara, K., \& Mwombela, S. (2012). The Governance of the Capitation Grant in Primary Education in Tanzania: Why Civic Engagement and School Autonomy Matter. Dar es Salaam: Repoa.

Matekere, Y., \& Van Aelst, K. (2014). Great Governance Project (P3) Research. Analysis of accountability mechanisms in the water and education sector. Case study for selected villages surrounding Mzumbe University. Mzumbe: University of Mzumbe.

Pahl-Wostl, C., Level, L., Knieper, C., \& Nikitina, E. (2012). From applying panaceas to mastering complexity: Towards adaptive water governance in river basins. Environmental Science \& Policy, 23, 24-34.

Prinsen, G. (2007). The parents, the patients and the privileged. Accountability and elite capture in schools and clinics in Uganda and Tanzania. Dar es Salaam: SNV Tanzania.

Rathwell, K. J., \& Peterson, G. (2012). Connecting Social Networks with Ecosystem Services for Watershed Governance: A Social-Ecological Network Perspective Highlights the Critical Role of Bridging Organizations. Ecology and Society, 17(2), 24.

Scott, J. (2011). Social Network Analysis. A Handbook. Los Angeles: Sage. 


\section{Macrothink $\triangle$ Institute}

Stein, C., Ernstson, H., \& Barron, J. (2011). A social network approach to analyzing water governance: The case of the Mkindo catchment, Tanzania. Physics and Chemistry of the Earth, 36, 1085-1092.

UNESCO. (2008). Overcoming inequality: Why governance matters. EFA Global Monitoring Report 2009. UNESCO: Paris.

United Republic of Tanzania. (2010). Local Government Reform Programme II (D by D). Action Plan and Budget July 2010 - June 2011. Dar es Salaam: The United Republic of Tanzania, Prime Minister's Office, Regional Administration and Local Government.

United Republic of Tanzania. (2013). School Improvement Toolkit. Practical Guide for Head Teachers and Heads of School. Dar es Salaam: United Republic of Tanzania, Ministry of Education and Vocational Training.

Uwazi. (n. d.). Key Institutions in RURAL local government. Dar es Salaam: Uwazi, Twaweza. Retrieved from http:/uwazi.org/uploads/files/Key\%20institutions\%20in\%20RURAL\%20local\%20gover nment\%20PPT.pdf

Venugopal, V., \& Yilmaz, S. (2010). Decentralization in Tanzania: An assessment of local government discretion and accountability. Public Administration and Development, 30, 215-231.

Wasserman, S., \& Faust, K. (1994). Social Network Analysis. Methods and Application. Cambridge: Cambridge University Press.

\section{Copyright Disclaimer}

Copyright reserved by the author(s).

This article is an open-access article distributed under the terms and conditions of the Creative Commons Attribution license (http://creativecommons.org/licenses/by/3.0/). 